\title{
Introduction: Real-World Evidence in Type 2 Diabetes
}

Mohamed Hassanein · Aslam Amod · Kamlesh Khunti ·

Moon-Kyu Lee $\cdot$ Viswanathan Mohan

Received: April 6, 2020 / Published online: May 21, 2020

(C) The Author(s) 2020

The International Diabetes Federation estimates that 463 million people are affected by diabetes worldwide, $79 \%$ of whom live in middle- or low-income countries [1]. Moreover, the number of people living with diabetes is predicted to increase by $51 \%$ in the next 25 years and reach 700 million by 2045 [1]. The greatest increases will be seen in Africa, Southeast Asia, and Central or South America [1]. Many of the people with diabetes in the world do not have access to the latest treatments recommended by

\section{Hassanein}

United Arab Emirates Department of

Endocrinology, Dubai Hospital, Dubai, United Arab Emirates

\section{A. Amod}

Life Chatsmed Garden Hospital and Nelson R.

Mandela School of Medicine, Durban, South Africa

\section{K. Khunti}

Leicester Diabetes Centre at University Hospitals of Leicester NHS Trust, Leicester, UK

\section{M.-K. Lee}

Division of Endocrinology and Metabolism, Department of Internal Medicine, Soonchunhyang University Gumi Hospital, Soonchunhyang University School of Medicine, Gumi,

Kyungsangbuk-do 39371, South Korea

V. Mohan $(\square)$

Dr. Mohan's Diabetes Specialities Centre and Madras Diabetes Research Foundation, Chennai, India

e-mail: drmohans@diabetes.ind.in guidelines for developed countries such as those from the American Association of Clinical Endocrinologists (AACE) [2], American Diabetes Association (ADA) and European Association for the Study of Diabetes (EASD) [3]. Nevertheless, these individuals in low- or middle-income countries deserve to receive effective and safe treatments, with proven benefits.

Randomised clinical trials are important to answer questions relating to drug efficacy and safety under controlled conditions that maximise statistical certainty ('can this product work?'). However, because of the strictly controlled conditions of a clinical trial, they need to be supplemented by data from real-world populations of patients to ensure that the findings are generalisable to a wider population of patients ('does it work?') [4,5]. Together the evidence from controlled trials and real-world studies provides guidance on how treatments will work in clinical practice.

Sulfonylureas represent an important class of agents for the treatment of type 2 diabetes mellitus (T2DM) as second-line therapy in patients who do not achieve optimal glycaemic control on metformin alone. Clinical trial data and real-world clinical experience with these agents have been accumulating for many decades. Moreover, these agents are inexpensive with a per-dose cost that is much lower than that of the newer classes of agents such as the sodium-glucose cotransporter 2 inhibitors 
(SGLT2i) or glucagon-like peptide-1 receptor agonists (GLP-1RA) [6].

SGLT2i and GLP1-RA are recommended for T2DM patients with cardiovascular disease based on evidence from the large-scale cardiovascular outcomes trials $[3,7,8]$, but the majority of patients with T2DM requiring second-line therapy do not have cardiovascular disease [9-11]. For patients without cardiovascular disease, international guidelines differ in their recommendations. Sulfonylureas are the agents of choice as add-on therapy to metformin in the World Health Organisation (WHO) guidelines for T2DM management in countries with limited resources [12]. They are also recommended as a preferred second-line therapy in guidelines from the International Diabetes Federation [13], UK National Institute for Health and Care Excellence [14] as well as professional bodies in Australia [15] and India [16]. AACE and ADA/EASD guidelines, however, recommend newer classes of agents ahead of sulfonylureas [2, 3], but these guidelines are consensus- rather than evidence-based and would score poorly on the Appraisal of Guidelines for Research and Evaluation (AGREE) scale for guideline quality [13]. Moreover, not all sulfonylureas are created equal, with gliclazide showing a more favourable effect on cardiovascular mortality than other sulfonylureas [17], and the lowest risk of hypoglycaemia [18].

The article in this supplement summarises the presentations at a symposium entitled "Real-world evidence and new perspectives with gliclazide MR" at the International Diabetes Federation Congress in Busan, South Korea, on 4 December 2019. These presentations described the place of sulfonylureas generally, and gliclazide MR specifically, in the treatment of T2DM and emerging real-world evidence to support this role, including in patients who are fasting during Ramadan. Finally, the article describes the role of sulfonylureas as first-line therapy in patients with a primary defect in insulin secretion-those with maturity onset diabetes of the young (MODY). The truly international focus of this symposium on the role of sulfonylureas provides insights into how these important agents can be used globally to improve outcomes in a range of patients with diabetes.

\section{ACKNOWLEDGEMENTS}

Funding. The Rapid Service fee for publication of this article was funded by Servier, France.

Medical Writing Assistance. The author would like to thank Catherine Rees, of Springer Healthcare Communications, who provided medical writing assistance with the first draft of this manuscript. This medical writing assistance was funded by Servier, France.

Authorship. All named authors meet the International Committee of Medical Journal Editors (ICMJE) criteria for authorship for this article, take responsibility for the integrity of the work as a whole, and have given their approval for this version to be published.

Prior Presentation. This article was based on the presentation given by the author at the symposium "Real-world evidence and new perspectives with gliclazide MR" during the Annual Meeting of the International Diabetes Federation (IDF) in Busan, Korea, 4 December 2019.

Disclosures. Mohamed Hassanein has attended the advisory board or received speaker honoraria for Servier, MSD, Novartis, Novo Nordisk, Sanofi-Aventis, Astra Zeneca and EliLily. Aslam Amod has served on advisory panels and participated in speaker bureaus and clinical trials for Aspen Pharmacare, AstraZeneca, Boehringer Ingelheim, Eli Lilly, MSD, Novartis, Novo Nordisk, Sanofi Aventis and Servier Laboratories. Kamlesh Khunti has served as a consultant and participated in speaker bureaus for, or received research support from, Amgen, AstraZeneca, Berlin-Chemie AG/Menarini Group, BMS, Boehringer Ingelheim, Janssen, Lilly, MSD, Napp, Novartis, Novo Nordisk, Roche, Sanofi and Servier. Moon-Kyu Lee has received funding support and speaker honoraria from Merck, Novartis, Novo Nordisk, Astra 
Zeneca and Servier. Viswanathan Mohan has received funding support and speaker honoraria from Servier, Novo Nordisk, Sanofi, Merck and other India-based pharmaceutical companies.

Compliance with Ethics Guidelines. This article is based on previously conducted studies and does not contain any studies with human participants or animals performed by the author.

Peer Review. Please note, contrary to the journal's standard single-blind peer review process, as an editorial this article underwent review by a member of the journal's Editorial Board.

Data Availability. Data sharing is not applicable to this article as no datasets were generated or analyzed during the current study.

Open Access. This article is licensed under a Creative Commons Attribution-NonCommercial 4.0 International License, which permits any non-commercial use, sharing, adaptation, distribution and reproduction in any medium or format, as long as you give appropriate credit to the original author(s) and the source, provide a link to the Creative Commons licence, and indicate if changes were made. The images or other third party material in this article are included in the article's Creative Commons licence, unless indicated otherwise in a credit line to the material. If material is not included in the article's Creative Commons licence and your intended use is not permitted by statutory regulation or exceeds the permitted use, you will need to obtain permission directly from the copyright holder. To view a copy of this licence, visit http:// creativecommons.org/licenses/by-nc/4.0/.

\section{REFERENCES}

1. International Diabetes Federation. IDF diabetes atlas, 9th edn. 2019. https://diabetesatlas.org/en/ resources/. Accessed 22 Jan 2020.

2. Garber AJ, Abrahamson MJ, Barzilay JI, et al. Consensus statement by the American Association of
Clinical Endocrinologists and American College of Endocrinology on the comprehensive type 2 diabetes management algorithm-2019 executive summary. Endocr Pract. 2019;25(1):69-100.

3. Davies MJ, D'Alessio DA, Fradkin J, et al. Management of hyperglycaemia in type 2 diabetes, 2018. A consensus report by the American Diabetes Association (ADA) and the European Association for the Study of Diabetes (EASD). Diabetologia. 2018; 61(12):2461-98.

4. Concato J, Shah N, Horwitz RI. Randomized, controlled trials, observational studies, and the hierarchy of research designs. $\mathrm{N}$ Engl $\mathrm{J}$ Med. 2000;342(25):1887-922.

5. Price D, Bateman ED, Chisholm A, et al. Complementing the randomized controlled trial evidence base. Evolution not revolution. Ann Am Thorac Soc. 2014;11(Suppl 2):S92-S9898.

6. Chahal $\mathrm{H}$, for WHO secretariat. Comparative review of oral hypoglycemic agents in adults: World Health Organization. https://www.who.int/ selection_medicines/committees/expert/19/applica tions/Oralhypoglycemics_18_5_A_R.pdf. Accessed 18 May 2020.

7. Cosentino F, Grant PJ, Aboyans V, et al. 2019 ESC Guidelines on diabetes, pre-diabetes, and cardiovascular diseases developed in collaboration with the EASD. Eur Heart J. 2020;41(2):255-32323.

8. Diabetes Canada Clinical Practice Guidelines Expert Committee, Houlden RL. 2018 Clinical practice guidelines. Can J Diabetes. 2018;42(Suppl 1): S1-S325.

9. Lage MJ. Comment on generalizability of GLP-1 RA CVOTs in US T2D population. Am J Manag Care. 2019;25(4):170-1.

10. Pintat S, Fenici P, Hammar N, et al. Eligibility of patients with type 2 diabetes for sodium-glucose cotransporter 2 inhibitor cardiovascular outcomes trials: a global perspective from the DISCOVER study. BMJ Open Diabetes Res Care. 2019;7(1): e000627.

11. Wittbrodt ET, Eudicone JM, Bell KF, Enhoffer DM, Latham K, Green JB. Generalizability of glucagonlike peptide-1 receptor agonist cardiovascular outcome trials enrollment criteria to the US type 2 diabetes population. Am J Manag Care. 2018;24(8 Suppl):S146-S155155.

12. World Health Organization. Guidelines on secondand third-line medicines and type of insulin for the control of blood glucose in non-pregnant adults with diabetes mellitus. Geneva: World Health Organization; 2018. 
13. International Diabetes Federation. IDF Clinical practice recommendations for managing type 2 diabetes in primary care. 2017. https://www.idf.org/ our-activities/care-prevention/type-2-diabetes. html. Accessed 21 Jan 2020.

14. National Institute for Health and Care Excellence. Type 2 diabetes in adults: management. 2015. https://www.nice.org.uk/guidance/ng28/resources/ type-2-diabetes-in-adults-management-pdf-183733 8615493. Accessed 21 Jan 2020.

15. Royal Australian College of General Practitioners. General practice management of type 2 diabetes. 2016. https://www.racgp.org.au/FSDEDEV/media/ documents/Clinical\%20Resources/Guidelines/Dia betes/General-practice-management-of-type-2diabetes_1.pdf. Accessed 21 Jan 2020.
16. Kalra S, Aamir AH, Raza A, et al. Place of sulfonylureas in the management of type 2 diabetes mellitus in South Asia: a consensus statement. Indian J Endocrinol Metab. 2015;19(5):577-96.

17. Simpson SH, Lee J, Choi S, Vandermeer B, Abdelmoneim AS, Featherstone TR. Mortality risk among sulfonylureas: a systematic review and network meta-analysis. Lancet Diabetes Endocrinol. 2015;3(1):43-51.

18. Maloney A, Rosenstock J, Fonseca V. A model-based meta-analysis of 24 antihyperglycemic drugs for type 2 diabetes: comparison of treatment effects at therapeutic doses. Clin Pharmacol Ther. 2019;105(5):1213-23. 